\title{
HUBUNGAN KEBAHAGIAAN DAN STATUS SOSIAL EKONOMI KELUARGA DI KELURAHAN ARTEMBAGA II KOTA BITUNG
}

\author{
${ }^{1}$ Gloria E. Wenas \\ ${ }^{2}$ Henry Opod \\ ${ }^{2}$ Cicilia Pali
}

\author{
${ }^{1}$ Kandidat Skripsi Fakultas Kedokteran Universitas Sam Ratulangi Manado \\ ${ }^{2}$ Bagian Psikologi Fakultas Kedokteran Universitas Sam Ratulangi Manado \\ Email: gloriawenas10_253@yahoo.com
}

\begin{abstract}
Happiness is the fulfillment of the necessities of life through a variety of ways. Happiness, virtue, success, and blessing are always sought by human. One of the factors that influence happiness is economic status. This study aimed to obtain the relationship of happiness and social economic status in people of Aertembaga II, Bitung. This was a qualitative study with samples of 90 people by using simple random sampling. Data were obtained by using questionnaire measured by modified Likert scale. Data were statistically analyzed by using the Chi Square correlation and SPSS 17 for Windows program. The result showed $r=0.269$ which meant that there was a correlation between happiness and social economic status with a low level of correlation (significance level 0.05). Conclusion: Happpiness was related to social economic status among people in Aertembaga II, Bitung. Keywords: happiness, social economic status
\end{abstract}

\begin{abstract}
Abstrak: Kebahagiaan dapat dicapai dengan terpenuhinya kebutuhan hidup melalui beraneka ragam cara yang ditempuh oleh masing-masing individu. Kebahagiaan sama halnya dengan kebaikan, kesuksesan dan keberkahan senantiasa dicari manusia. Salah satu faktor yang memengaruhi kebahagiaan ialah status ekonomi. Penelitian ini bertujuan untuk mengetahui ada tidaknya hubungan kebahagiaan dengan status sosial ekonomi pada warga Kelurahan Aertembaga II Kota Bitung. Penelitian ini merupakan penelitian kualitatif korelasional dengan jumlah sampel sebanyak 90 orang. Pengambilan sampel dilakukan dengan cara simple random sampling (sampling acak). Data diambil menggunakan kuesioner dan diukur dengan modifikasi skala Likert. Metode analisis data dilakukan dengan teknik korelasi Chi Square dengan bantuan program SPSS 17 for windows. Hasil penelitian memperlihatkan $r=0,269$ yang menunjukkan terdapat hubungan antara kebahagiaan dan status sosial ekonomi dengan tingkat hubungan yang rendah pada taraf signifikansi 0,05. Kebahagiaan pada warga kelurahan Aertembaga II dalam kategori bahagia sebesar 61,1\%, dengan status sosial ekonomi 60,0\% pada kategori tinggi. Simpulan: Terdapat hubungan antara kebahagiaan dengan status sosial ekonomi dengan tingkat hubungan yang rendah.
\end{abstract}

Kata kunci: kebahagiaan, status sosial ekonomi

Kebahagiaan merupakan suatu hal yang penting dalam kehidupan tanpa melihat batas usia seseorang. Kebahagiaan merupakan sebongka perasaan yang dapat dirasakan berupa perasaan senang, tentram, dan memiliki kedamaian. Kebahagiaan juga didefinisikan sebagai keadaan psikologis positif yang ditandai dengan tingginya derajat kepuasan hidup, afek positif, dan rendahnya derajat afek negatif. ${ }^{1}$

Semua orang menginginkan kebahagiaan dalam hidupnya, bahkan menurut Aristoteles kebahagiaan merupakan tujuan utama dari eksistensi 
manusia. Setiap orang juga memiliki harapan-harapan yang ingin dicapai guna pemenuhan kepuasan dalam kehidupannya. Kebahagiaan dan kepuasan dalam hidup merupakan bagian dari konsep kesejahteraan subjektif yang mencakup aspek afektif dan kognitif manusia. Kebahagiaan merupakan konsep yang subjektif karena setiap individu memiliki tolak ukur kebahagiaan yang berbedabeda. $^{2,3}$

Menurut Saligman, kebahagiaan yang sebenarnya berasal dari pemahaman terhadap kekuatan karakter yang dimiliki dan menanamkan serta menggunakannya dalam seluruh aspek kehidupan. Hasil survei pada tahun1995 sampai dengan 2007 yang dilakukan di 97 negara menunjukkan bahwa Indonesia merupakan negara yang memiliki skor kebahagiaan peringkat ke 40 dari 97 negara. Dari hasil survei tersebut diketahui bahwa Indonesia memiliki tingkat kebahagiaan yang lebih tinggi daripada negara Jepang dan Cina yang merupakan negara maju dan kaya. Hal ini menunjukkan bahwa status sosial saja belum bisa dijadikan ukuran kebahagiaan. ${ }^{3}$

Shahar memberikan kiat untuk bertanya dengan kata bantu "why" untuk mendapatkan tolok ukur kebahagiaan seperti mengapa seseorang ingin kaya, memiliki mobil baru, menjadi terkenal atau sukses? Jawabanya akan bermuara karena yang bersangkutan ingin bahagia. Apabila diteruskan dengan pertanyaan alasan seseorang ingin bahagia, maka tidak ada jawaban lain yang lebih baik daripada memang tujuan seseorang adalah hidup bahagia. Semua tolok ukur baik kekayaan material, popularitas, kepuasaan spiritual maupun emosional hanya akan bermuara ke satu kata yaitu bahagia, meskipun pada beberapa literature dikatakan bahwa kebahagiaan bisa bersumber dari kekayaan dan pekerjaan atau status sosial ekonomi. ${ }^{3,4}$

Dalam kamus besar bahasa Indonesia, kata sosial berarti segala sesuatu yang berkaitan dengan masyarakan sedangkan, dalam konsep sosiologi manusia sering disebut sebagai makhluk sosial yang artinya manusia tidak dapat hidup wajar tanpa ada bantuan orang lain disekitar sehingga kata-kata sosial dapat ditafsirkan hal-hal yang berkaitan dengan masyarakat. Sementara istila ekonomi sendiri berasal dari bahasa Yunani yakni "oikos" yang berarti keluarga atau rumah tangga dan "nomos" peraturan aturan hukum. Maka secara garis besar ekonomi diartikan sebagai peraturan rumah tangga atau menejemen rumah tangga. ${ }^{4}$

Winke menyatakan bahwa pengertian status sosial mempunyai makna suatu keadaan yang menunjukkan pada kemampuan finansial keluarga dan perlengkapan material yang dimiliki, dimana keadaan bertaraf baik, cukup atau kurang. Sosial ekonomi juga dapat diartikan keadaan atau kedudukan suatu kesatuan sosial terkecil yang terdiri atas suami, istri, dan anak yang diatur secara sosial dalam posisi tertentu dalam struktur masyarakat yang menentukan hak dan kewajiban seseorang dalam masyarakat. ${ }^{5,6}$

Berdasarkan beberapa pengertian di atas maka dapat disimpulkan bahwa sosial ekonomi merupakan segala sesuatu yang berkaitan dengan pemenuhan kebutuhan yang ada di masyarakat atau yang lebih umumnya terkait dengan kesejahteraan masyarakat. Tan mengatakan status sosioekonomi dapat dilihat dari pekerjaan, pendidikan kesehatan dan pemenuhan kebutuhan hidup dalam rumah tangga. Berdasarkan ini masyarakat dapat digolongkan kedudukan sosial ekonomi atas, menegah dan bawah. ${ }^{4}$

Geimar dan Lasorte membagi keluarga atas 4 tingkat ekonomi: adekuat, marginal, miskin, dan sangat miskin. Terdapat 3 kelas atau golongan ekonomi menurut Aristoteles yaitu golongan sangat kaya, golongan kaya, golongan miskin. Faktor yang memengaruhi status ekonomi seseorang yaitu pendidikan, pekerjaan, keadaan ekonomi, latar belakang budaya dan pendapatan. $^{7}$

\section{METODE PENELITIAN}

Penelitian ini bersifat analitik untuk mengetahui hubungan antara variabel terikat dan variabel bebas, yaitu variabel 
kebahagiaan dan status sosial pada keluarga. Populasi penelitian ini ialah keluarga-keluarga di kelurahan Aertembaga II, kecamatan Aertembaga, Kota Bitung. Jumlah sampel sebanyak 90 keluarga dan pengambilan sampel menggunakan metode Simple Random Sampling.

\section{HASIL PENELITIAN}

Tabel 1 menunjukkan bahwa tingkat social ekonomi rendah terbanyak adalah 24 orang $(66,7 \%)$ pada responden laki-laki, diikuti 12 orang (33,3\%) pada responden perempuan. Sedangkan tingkat social ekonomi tinggi yang paling banyak adalah 29 orang (53,7\%) pada responden laki-laki, diikuti 25 orang $(46,3 \%)$ pada respoden perempuan.

Tabel 2 menunjukkan bahwa tingkat social eknomi rendah yang paling banyak adalah 14 orang $(38,9 \%)$ pada rentang umur 31 sampai dengan 40 tahun juga pada rentang umur 41-50 tahun, dan yang paling sedikit adalah pada rentang umur di atas 50 tahun yaitu sebanyak 8 orang (22,2\%).
Sedangkan pada tingkat sosial ekonomi tinggi yang paling banyak adalah 30 orang (55,6\%) pada rentang umur 41 sampai dengan 50 tahun, diikuti 16 orang (29,6\%) pada rentang umur 31 sampai dengan 40 tahun, dan yang paling sedikit adalah responden dengan rentang umur di atas 50 tahun yaitu sebanyak 8 orang (22,2\%).

Tabel 3 menunjukkan bahwa responden dengan tingkat social ekonomi rendah terbanyak ialah 20 orang (55,7\%) dengan tingkat pendidikan SMA, diikuti 7 orang $(19,4 \%)$ dengan tingkat pendidikan SD dan tingkat pendidikan SMP sebanyak 6 orang (16,7\%), yang paling sedikit adalah perguruan tinggi yaitu sebanyak 3 orang (8,3\%). Responden dengan tingkat sosial ekonomi tinggi yang paling banyak adalah 20 orang $(37,0 \%)$ dengan tingkat pendidikan SMP, diikuti tingkat pendidikan SMA sebanyak 17 orang (31,5\%), tingkat pendidikan SD sebanyak 11 orang $(20,4 \%)$ dan yang paling sedikit adalah tingkat pendidikan perguruan tinggi yaitu sebanyak 6 orang $(11,1 \%)$.

Tabel 1. Distribusi Responden Berdasarkan Jenis Kelamin

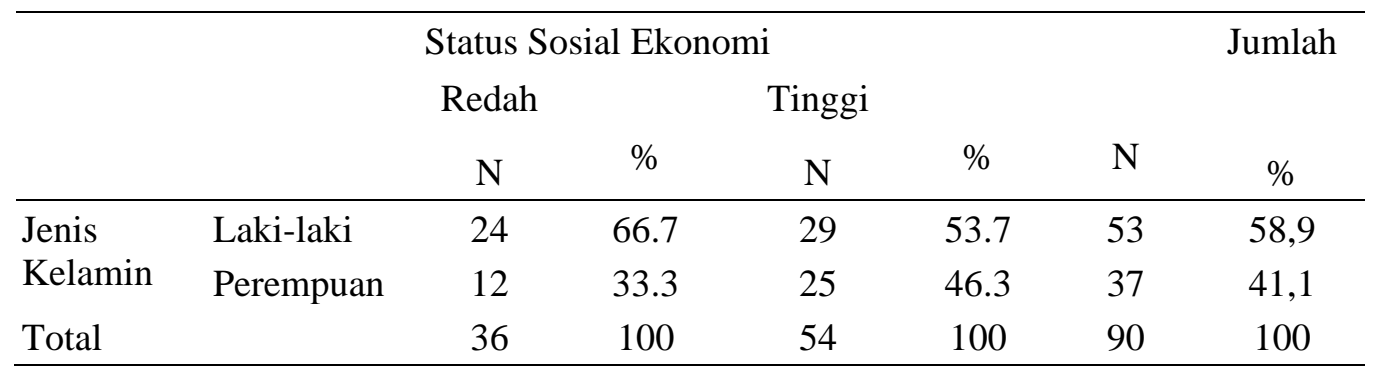

Tabel 2. Distribusi Responden Berdasarkan Umur

\begin{tabular}{|c|c|c|c|c|c|c|c|}
\hline & & & atus So & Ekono & & & Jumlah \\
\hline & & Rendah & & Tingg & & & \\
\hline & & $\mathrm{N}$ & $\%$ & $\mathrm{~N}$ & $\%$ & $\mathrm{~N}$ & $\%$ \\
\hline Umur & 31-40 Thn & 14 & 38,9 & 16 & 29,6 & 30 & 33,3 \\
\hline & 41-50 Thn & 14 & 38,9 & 30 & 55,6 & 44 & 48,9 \\
\hline & > 50 Thn & 8 & 22,2 & 8 & 22,2 & 16 & 17,8 \\
\hline Total & & 36 & 100 & 54 & 100 & 90 & 100 \\
\hline
\end{tabular}


Wenas, Opod, Pali: Hubungan kebahagiaan dan status sosial ekonomi keluarga ...

Tabel 3. Distribusi Responden Berdasarkan Tingkat Pendidikan

\begin{tabular}{llcccccc}
\hline & \multicolumn{3}{c}{ Status Sosial Ekonomi } & & Jumlah \\
& & Redah & \multicolumn{3}{c}{ Tinggi } \\
& $\mathrm{N}$ & $\%$ & $\mathrm{~N}$ & $\%$ & $\mathrm{~N}$ & $\%$ \\
\hline Tingkat & SD & 7 & 19,4 & 11 & 20,4 & 18 & 20,0 \\
Pendidikan & SMP & 6 & 16,7 & 20 & 37,0 & 26 & 28,9 \\
& SMA & 20 & 55,7 & 17 & 31,5 & 37 & 41,1 \\
& Perguruan & 3 & 8,3 & 6 & 11,1 & 9 & 10,0 \\
Total & Tinggi & & & & & & \\
& & 36 & 100 & 54 & 100 & 90 & 100 \\
\hline
\end{tabular}

Tabel 4 menunjukan bahwa responden dengan tingkat social ekonomi rendah sebanyak 20 orang $(55,6 \%)$ tidak merasa bahagia, sedangkan 16 orang merasa bahagia, dan responden dengan tingkat social ekonomi tinggi sebanyak 39 orang (72,2\%) merasa bahagia, sedangkan 15 orang $(27,8 \%)$ tidak merasa bahagia.

Tabel 4. Tabulasi silang hubungan Kebahagiaan dengan Status Sosial Ekonomi

\begin{tabular}{llcccccc}
\hline & \multicolumn{9}{c}{ Status Sosial Ekonomi } & & Jumlah \\
& & Redah & \multicolumn{3}{c}{ Tinggi } \\
& & $\mathrm{N}$ & $\%$ & $\mathrm{~N}$ & $\%$ & $\mathrm{~N}$ & $\%$ \\
\hline Kebahagiaan & Ya & 16 & 44,4 & 39 & 72,2 & 55 & 61,1 \\
& Tidak & 20 & 55,6 & 15 & 27,8 & 35 & 38,9 \\
Total & 36 & 100 & 54 & 100 & 90 & 100 \\
\hline
\end{tabular}

\section{Uji statistik}

\section{Uji normalitas}

Data dikatakan berdistribusi normal apabila sig $>0,05$. Hasil uji normalitas
Kolmogrov-Smirnov dapat dilihat pada Tabel 5. Nilai sig variabel $\mathrm{x}$ dan y bernilai 0,000 dengan kata lain sig $<0,005$ yang berarti distribusi tidak normal.

Tabel 5. Uji Normalitas dengan Kolmogorov-Smirnov Test

\section{One-Sample Kolmogorov-Smirnov Test}

\begin{tabular}{|c|c|c|c|}
\hline & Var_X & Var_Y \\
\hline \multicolumn{2}{|l|}{$\mathrm{N}$} & 90 & 90 \\
\hline \multirow{5}{*}{$\begin{array}{l}\text { Normal } \\
\text { Parameters }{ }^{\mathrm{a}} \\
\text { Most Extreme } \\
\text { Differences }\end{array}$} & Mean & 1.61 & 1.60 \\
\hline & Std. Deviation & .490 & .493 \\
\hline & Absolute & .397 & .392 \\
\hline & Positive & .283 & .288 \\
\hline & Negative & -.397 & -.392 \\
\hline \multicolumn{2}{|c|}{ Kolmogorov-Smirnov Z } & 3.769 & 3.715 \\
\hline \multicolumn{2}{|c|}{ Asymp. Sig. (2-tailed) } & .000 & .000 \\
\hline
\end{tabular}




\section{Uji Liniearitas}

Kedua variabel berkorelasi secara linear jika nilai F hitung lebih besar dibanding F tabel. Kriteria uji liniearitas ialah:

- Jika F hitung >F tabel, maka kebahagiaan dan status sosial ekonomi berkorelasi secara linier

- Jika $\mathrm{F}$ hitung $<\mathrm{F}$ tabel, maka kebahagiaan dan status sosial ekonomi tidak berkorelasi secara linier

Pada uji linearitas diatas diperoleh nilai F sebesar 7,437 dengan nilai probabilitas (sig) $=0,008, \mathrm{df}=1$ dan $\mathrm{df} 2=90$, maka nilai F tabel = 3,95 (Tabel 6). Dengan demikian diperoleh hasil 7,437 > 3,95 atau F hitung > F tabel, artinya H1 diterima dan Ho ditolak atau dengan kata lain terdapat hubungan yang linier antara kebahagiaan dengan status sosial ekonomi.

\section{Uji Korelasi}

Korelasi digunakan untuk melihat ada tidaknya hubungan antara variabel Kebahagiaan dengan Sosial Ekonomi. Metode yang dipilih dalam menghitung koefisien korelai tersebut adalah ChiSquare dengan menggunakan SPSS 17 for windows.

Hipotesis penelitian yang diuji ialah :

- H0: tidak ada hubungan antara variabel kebahagiaan dan status sosial ekonomi

- H1: ada hubungan antara variabel kebahagiaan dengan status sosial ekonomi

Jika nilai koefisien korelasi $=1$ maka kedua variabel dikatakan berkorelasi secara sempurna. Semakin dekat nilai $r$ dengan angka 1 maka semakin kuat korelasi kedua variabel yang diteliti. Dari total sampel sebanyak 90 sampel, diperoleh koefisien korelasi Chi Square yang bernilai positif sebesar 0,269 dengan nilai $\mathrm{p}=0,008$ (Tabel 7). Nilai $r=0,269>0$, maka disimpulkan terdapat hubungan antara kebahagiaan dengan status sosial ekonomi dengan tingkat hubungan yang rendah. Probabilitas koefisien korelasi (r) telah memenuhi taraf signifikansi 0,05 dimana nilai sig $<\alpha=$ $0,008<0,05$ atau 5\% kesalahan dari 100\%.

Tabel 6.Uji Liniearitas

\begin{tabular}{|c|c|c|c|c|c|c|}
\hline \multicolumn{2}{|c|}{ Model } & $\begin{array}{l}\text { Sum of } \\
\text { Squares }\end{array}$ & $\mathrm{df}$ & Mean Square & $\mathrm{F}$ & Sig. \\
\hline \multirow[t]{3}{*}{1} & Regression & 1.683 & 1 & 1.683 & 7.437 & $.008^{\mathrm{a}}$ \\
\hline & Residual & 19.917 & 88 & .226 & & \\
\hline & Total & 21.600 & 89 & & & \\
\hline
\end{tabular}

a. Predictors: (Constant), Var_X

b. Dependent Variable: Var_Y

Tabel 7. Hasil uji Korelasi Chi-Square

Symmetric Measures

\begin{tabular}{|c|c|c|c|}
\hline & & Value & $\begin{array}{c}\text { Approx. } \\
\text { Sig. }\end{array}$ \\
\hline $\begin{array}{l}\text { Nominal by } \\
\text { Nominal } \\
\text { N of Valid C }\end{array}$ & $\begin{array}{l}\text { Contingency } \\
\text { Coefficient }\end{array}$ & & .008 \\
\hline
\end{tabular}




\section{BAHASAN}

Sesuai dengan hasil penelitian di atas ditemukan bahwa terdapat hubungan antara kebahagiaan dengan status social ekonomi pada masyarakat di kelurahan Aertembag II kota Bitung pada taraf signfikansi 0,05. Pada variabel kebahagiaan, dapat dilihat pada tabel distribusi sebelumnya, diketahui bahwa sebagian besar responden menyatakan bahagia dengan presentase sebesar $61,1 \%$. Hal ini sesuai dengan teori bahwa beberapa individu yang merasa bahagia walaupun terdapat hambatan personal, tragedi, dan kekurangan cinta atau kekayaan, sedangkan beberapa individu lain merasa tidak bahagia walaupun dikelilingi oleh berbagai kenyamanan dan keuntungan. Orang yang mampu merasa bahagia berarti telah melakukan penilaian terhadap kebahagiaanya secara menyeluruh, kemudian membandingkan dengan orang lain dan mampu membuat suatu karakteristik antara kebahagiaan dan tidak bahagia.

Penilaian individu terhadap kebahagiaannya secara keseluruhan menyatakan bahwa dalam penelitian ini responden telah merasa puas terhadap keadaannya saat ini dan tidak merasa adanya ancaman dalam kebutuhan dasar manusia sehingga kebahagiaan menjadi seperti saat ini, Hal ini sesuai dengan Teori yang dikemukakan oleh Abrham Maslow bahwa ketika Kebutuhan Dasar/fisiologi telah terpenuhi maka rasa aman akan terwujud dengan sendirinya.

$$
\text { Mampu menilai kebahagiaan }
$$
merupakan hal pertama yang semestinya ada pada individu, karena arti kebahagiaan bagi setiap individu realtif berbeda sehingga kebahagiaan itu sendiri bagi sebagian orang merupakan suatu keadaan pikiran atau perasaan yang ditandai dengan kesenangan, cinta, kepuasan, kenikmatan, atau kegembiraan namun bagi orang lain makna kebahagiaan berbeda-beda.

Dikaitkan dengan status sosisal ekonomi, berdasarkan hasil penelitian yang ditunjukan oleh tabel yang telah dibahas sebelumnya dapat dilihat bahwa sebagian besar status sosial ekonomi responden termasuk dalam kategori tingkat sosisal ekonomi yang tinggi yaitu 54 responden atau (60,0\%), sedangkan tingkat ekonomi rendah yaitu 36 responden $(40,0 \%)$ hal ini sesuai dengan teori yang dikemukakan oleh Lyubomirsky, S \& Leppe, H.S. (1997), bahwa Kelas sosial turut menentukan pekerjaan, pendapatan, kesehatan, serta gaya hidup dalam menghabiskan waktu luang. Hal ini membuat individu yang berada pada kelas sosial menengah ke atas cenderung lebih bahagia sedangkan, Secara umum, orang yang memiliki pendapatan lebih tinggi lebih bahagia dibandingkan orang yang berpendapatan rendah. Namun hubungan ini tidak terlalu kuat. Perubahan dalam pendapatan juga dapat menimbulkan efek negatif terhadap kebahagiaan individu. $^{9}$

Penilaian individu terhadap karakteristik orang yang bahagia dan tidak bahagia menentukan sikap sesorang tentang arti kebahagiaan bagi diri sendiri. Dikaitkan dengan hasil penelitian bahwa ada hubungan antara kebahagiaan dengan status social ekonomi dengan tingkat hubungan yang rendah bermakna bahwa kebahagiaan tidak selamnya di tentukan oleh status social ekonomi meskupun factor pendapatan yang merupakan salah satu indicator status social ekonomi termasuk dalam menentukan kebahagiaan seseorang. Dengan sendirinya kebahagiaan terwujud apabila rasa aman dan nyaman, rasa saling mencintai dan di hargai mampu dipenuhi meskipun pada kondisi status ekonomi yang rendah, atau dengan kata lain kebahagiaan bukan di ukur dengan banyaknya materi atau atau fisik tapi tentang sebuah kenyamanan hati.

\section{SIMPULAN}

Nilai Kebahagiaan dalam kehidupan berkeluarga dan bersosial pada penelitian ini menunjukan bahwa kebahagiaan tidak secara langsung dipengaruhi oleh status sosial ekonomi hal ini dibuktikan dengan hasil uji statistic yang menunjukan nilai koefisien korelasi $(r)=0,269$ yang bermakna tingkat hubungan yang rendah 
pada kedua variabel atau dengan kata lain terdapat hubungan antara kebahagiaan dengan status sosial ekonomi dengan tingkat hubungan yang rendah.

\section{DAFTAR PUSTAKA}

1. Mardayeti D. Gambaran Kebahagiaan Pada Anak Jalanan; p. 65-77. Available from: http://ejournal.unp.ac.id/students/ind ex.php/psi/article/download/599/358.

2. Ningsih DA. Subjective Well Being Ditinjau Dari Faktor Demografi. Universitas Muhammadiyah Malang 2013: 581-603.

3. Akmal S. Kekuatan Karakter Dan Kebahagiaan Pada Suku Minang, Universitas Indonesia 2009: 16-24

4. Zunaidi M. Kehidupan Sosial Ekonomi Pedagang Di Pasar Tradisional Pasca Relokasi Dan Pembangunan Pasar Moderen 2013: 51-64

5. Basrowi, Juriyah S. Analisis Kondisi Sosial Ekonomi Dan Tingkat Pendidikan Masyarakat Desa
Srigading, Kec Labuhan Maringgai, Kabupaten Lampung Timur 2010: 58-81

6. Barus CP. Sosial Ekonomi Keluarga dan Hubungannya dengan Kenakalan Remaja di Desa Lantasan Baru Kecamatan Patumbak Kab Deli Serdang: 1-9

7. Anonim, 2010. Konsep Dasar Status Ekonomi. Available from: http://dr.suparyanto.blogspot.com/20 10/07/konsep-dasar-statusekonomi.html. 29 Juli 2010

8. Widyanti RN. Gambaran Kebahagiaan dan Kepuasan Hidup pada Penderita Skizofrenia. Universitas Indonesia 2009: $1-9$

9. Lyubomirsky S, Leppe HS. (1997). Measures of Subjective Happiness: Preliminary Reliability and Construct Validation. Social Indicators Research46:137-155. Available from:

http://www.springerlink.com/content /u07421g90j170805/fulltext.pdf 